ISSN 0258-7122

Bangladesh J. Agril. Res. 39(1): 79-92, March 2014

\title{
ADOPTION OF RECOMMENDED POTATO (Solanum tuberosum) PRODUCTION TECHNOLOGIES BY THE POTATO GROWERS OF SOME SELECTED AREAS OF BANGLADESH
}

\author{
MD. IBRAHIM KHALIL ${ }^{1}$ MD. ENAMUL HAQUE ${ }^{2}$ \\ AND MUHAMMAD ZIAUL HOQUE ${ }^{3}$
}

\begin{abstract}
The main objective of this study was to determine the extent of adoption of improved potato production technologies by the potato growers. Data were collected from 231 potato growers of three highly concentrated potato growing Upazilas, namely Pirgachha (Rangpur), Munshiganj Sadar (Munshiganj), and Shibganj (Bogra) during October 2010 to February 2011. The potato growers showed marked individual differences in their socio-economic characteristics and majority of them belonged to middle age category having small family size, primary level of education, small farm size, medium innovativeness, and medium contact with extension personnel. The study revealed that highest proportion of the respondents in Munshiganj Sadar belonged to high adoption category in case of BARI recommended potato variety $(72.6 \%)$, optimum planting time $(87.7 \%)$, use of balanced fertilizers $(45.2 \%)$, whereas medium adoption categories were found in quality potato seed $(52.1 \%)$, proper seed size (47.9\%), fertilizer application methods (71.2\%), optimum irrigation (89\%), earthing up (84.9\%), plant protection $(74 \%)$, and low adoption categories were found in maintaining proper spacing (42.5\%). In Pirganj of Rangpur, highest proportion of the respondents belonged to high adoption category in case of BARI recommended potato variety $(77 \%)$, optimum planting time $(83.8 \%)$, whereas medium adoption categories were found in the use of quality potato seed $(64.9 \%)$, balanced fertilizer $(43.2 \%)$, proper seed size $(52.7 \%)$, fertilizer application methods $(87.8 \%)$, optimum irrigation (97.3\%), earthing up $(86.5 \%)$, plant protection $(93.2 \%)$, and low adoption categories were found in maintaining proper spacing $(64.9 \%)$. In Shibganj of Bogra, highest proportion of the respondents were found in high adoption category in case of BARI recommended potato variety $(75 \%)$, optimum planting time $(86.9 \%)$, whereas medium adoption categories were found in use of quality potato seed $(52.4 \%)$, balanced fertilizers $(47.6 \%)$, fertilizer application methods $(78.6 \%)$, optimum irrigation $(95.2 \%)$, earthing up $(88.1 \%)$, plant protection $(76.2 \%)$, and low adoption categories were found in maintaining proper spacing $(59.5 \%)$ and proper seed size $(57.1 \%)$. The study also revealed that highest $(53.4 \%)$ proportion of the respondents in Munshiganj Sadar belonged to high potato yield
\end{abstract}

\footnotetext{
${ }^{1}$ Deputy Director, Bangladesh Agricultural Development Corporation (BADC) \& Ph.D Fellow, Department of Extension and Rural Development, Bangabandhu Sheikh Mujibur Rahman Agricultural University (BSMRAU), Gazipur, ${ }^{2}$ Professor, Department of Extension and Rural Development, BSMRAU, ${ }^{3}$ Lecturer, Department of Agricultural Extension and Rural Development, BSMRAU, Gazipur, Bangladesh.
} 
(above 29 ton/ha) farmer category while medium potato yield (between 19 to 29 t/ha) category were found in other two areas i.e., Shibganj (58.80\%) and Pirgachha (79.50\%). Education, farm size, subsistence pressure, annual income, contact with the sources of information, farming experience, attitude, and knowledge on potato production showed significant positive relationship with adoption of improved potato production technologies.

Keywords: Technology, potato production, adoption, yield.

\section{Introduction}

Potato (Solanum tuberosum) is the third largest food crop in Bangladesh and has recently occupied an important place in the list of major food and cash crops of Bangladesh (Ali and Haque, 2011). The crop ranks first among the vagetables in Bangladesh both in area and production (BBS, 2006). Its area and production are increasing day by day (BBS, 2009). Ensuring food security for all is one of the major challenges in Bangladesh today. So, to ensure adequate food supply, it is necessary to give thrust to increase food production using improved variety and recommended practices. The adoption of recommended practices of potato production by the farmers could easily raise food production and net income of the users (Amin and Islam, 2009). Usually farmers follow a different levels of production technologies depending upon their infrastructural facilities and socioeconomic conditions which ultimately resulted in variability in yields of potato (Elias et al., 1992). Farmer's production performance depends on physical resources and technology available to them as well as existing farm management conditions. Efficient use of inputs and technologies could help farmers to get higher production from a given amount of resources. In view of the above discussion, the study attempted to achieve the following specific objectives:

(i) to determine the extent of adoption of improved potato production technologies by the potato growers in some selected study areas of Bangladesh;

(ii) to determine the potato yield obtained by the potato growers and find out the relationships between adoption of improved potato production technologies and yield;

(iii) to findout the relationships between socio-economic characteristics of the respondents and their adoption of improved potato production technologies.

\section{Methodology}

This descriptive and diagnostic type research aimed at determining the extent of adoption of improved potato production technologies by the potato growers of 
Bangladesh. The study was conducted in most concentrated potato growing areas viz., Pirgachha of Rangpur district, Munsiganj Sadar of Munsiganj district and Shibganj of Bogra district of Bangladesh.

Population and sample of the study: All the adult male and female potato growers of the selected villages, namely Nobtiganj and Bara Darga of Pirgachha Upazila, Sholarchar and Bakultala of Munsiganj Sadar Upazila and Apson and Belie of Shibganj Upazila constituted the total eligible population of the study. A list of the eligible units of the population of six selected villages i.e., sampling frame was prepared. Of the total eligible units of population of the study 77 and108 of Nobtiganj and Bara Darga villages, 85 and 98 of Sholarchar and Bakultala villages, 122 and 91 units of Apson and Belie villages were selected. From the eligible population (581), 231 potato farmers were selected as sample following proportionate random sampling technique (Kothari, 2004). The selected respondents were distributed proportionately to each of the selected village according to the number of population units.

Data collection: A pre-tested interview schedule was used to collect data from the respondents during October 2010 to February 2011 by the researcher. In order to collect relevant information from the potato farmers, an interview schedules was carefully designed keeping the objectives of the study. The information included both open and closed form questions. After the development of questionnaire, it was subjected to be pilot testing. Thus, 20 farmers similar to the study group were interviewed. The final versions of the instruments were revised on the basis of pre-test experience.

\section{Determination of extent of adoption of improved potato production technologies:}

Following parameters were considered to determine the extent of adoption rate (Table 1).

Extent of Adoption of improved potato production technologies was calculated by using the following formula (Kashem, 2004).

Extent of adoption $=\frac{\text { Area under potatocovered by each technology }}{\text { Totalarea under potatoby each farmer }} \times 100$

Appropriate methods were used to measure the personal and socio-economic characteriustics of the potato growers. 
Table 1. Parameters of improved technologies for potato production.

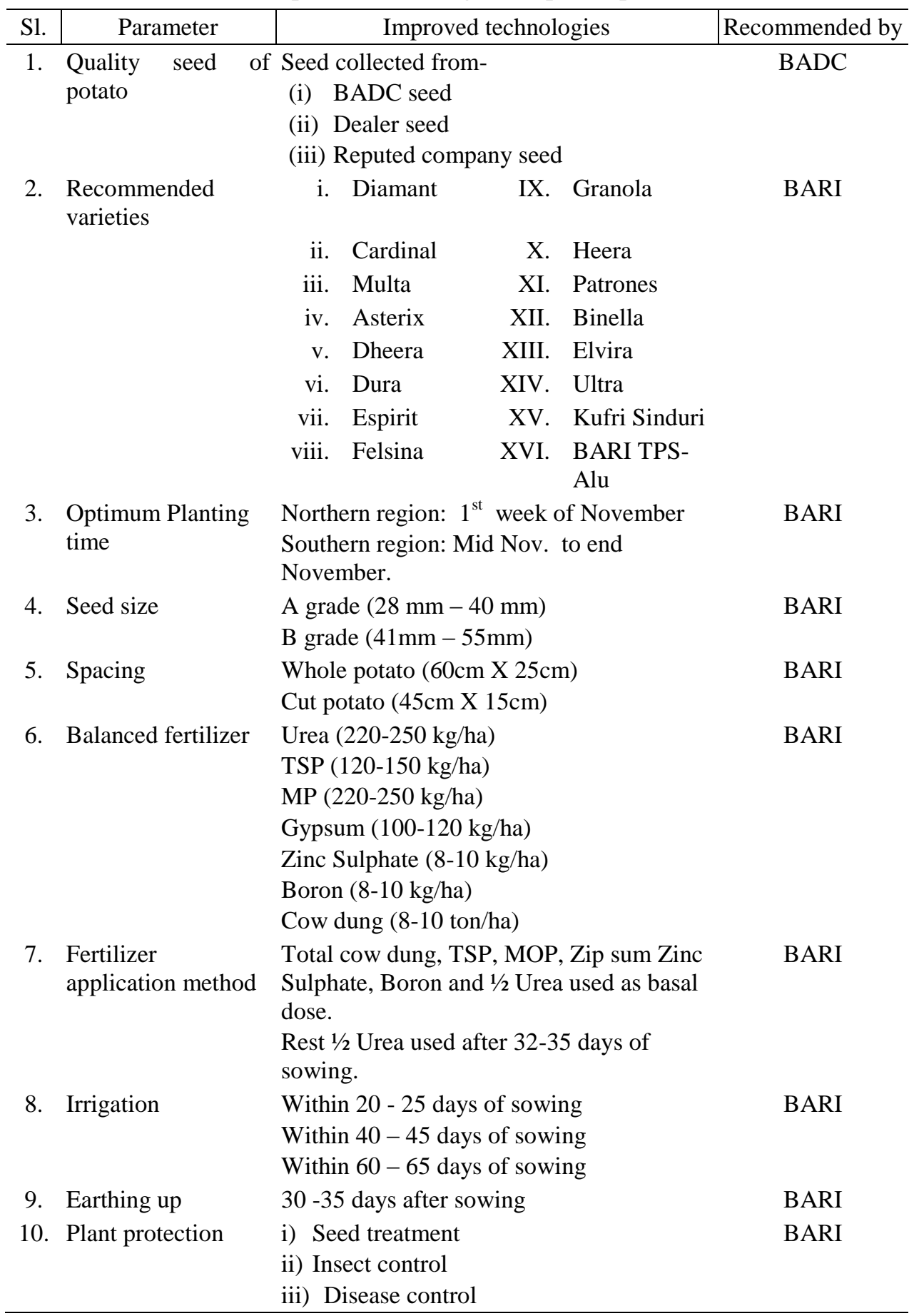


Data processing and statistical analysis: After collection of data, all the information contained in the interview schedule were edited. All the collected data were then checked and cross checked, compiled, coded, and entered into the computer for analysis and interpretation using SPSS programme. Qualitative data were converted into quantitative form by means of suitable scoring. For presentation of data various statistical measures, such as number, range, mean, percentage, and standard deviation were used to describe selected characteristics of the potato farmers. Coefficients of correlation ( $r$ ) were computed to find out the relationship between adoption of improved potato production technologies and potato yield. Multiple regression was conducted to find out the influence of the technological factors on potato yield.

\section{Results and Discussion}

\section{Socio-economic characteristics of the potato growers}

The socio-economic characteristics of potato farmers inncluded age, years of schooling, family size, farm size, subsistence pressure, farming experience, organizational participation, extension contact, participation in training programme, innovativeness, attitude towards improved potato production technologies, and knowledge on improved potato production technologies. These are described in Table 2.

Table 2. Distribution of the respondent according to their socio-economic characteristics.

\begin{tabular}{|c|c|c|c|c|c|}
\hline Characters & Unit & Categories & $\%$ & Mean & $\mathrm{SD}$ \\
\hline \multirow{3}{*}{$\begin{array}{l}\text { Age of the } \\
\text { respondent }\end{array}$} & \multirow{3}{*}{$\begin{array}{l}\text { Actual } \\
\text { year }\end{array}$} & Young aged (24 to 35$)$ & 34.2 & \multirow{3}{*}{41.11} & \multirow{3}{*}{9.60} \\
\hline & & Middle aged (36-50) & 50.6 & & \\
\hline & & Old $(>50)$ & 15.2 & & \\
\hline \multirow{5}{*}{$\begin{array}{l}\text { Years of } \\
\text { Schooling of } \\
\text { the respondent }\end{array}$} & \multirow{5}{*}{$\begin{array}{l}\text { Year of } \\
\text { schooling }\end{array}$} & No education $(0)$ & 32 & \multirow{5}{*}{4.44} & \multirow{5}{*}{3.69} \\
\hline & & Primary (1-5) & 29.9 & & \\
\hline & & Secondary $(6-10)$ & 34.2 & & \\
\hline & & Higher secondary (11 to 12 ) & 2.6 & & \\
\hline & & Above higher secondary $(>12)$ & 1.3 & & \\
\hline \multirow[t]{3}{*}{ Family size } & \multirow[t]{3}{*}{ Number } & Small (up to 4) & 47.2 & \multirow{3}{*}{4.82} & \multirow{3}{*}{1.42} \\
\hline & & Medium (5 to 6 ) & 41.6 & & \\
\hline & & Large ( 7 and above) & 11.3 & & \\
\hline \multirow[t]{3}{*}{ Farm size } & \multirow{3}{*}{$\begin{array}{l}\text { Actual } \\
\text { (ha) }\end{array}$} & Small (>0.03 to 1$)$ & 11.3 & \multirow{3}{*}{0.99} & \multirow{3}{*}{0.88} \\
\hline & & Medium (>1 to 3 ) & 56.3 & & \\
\hline & & Large (above 3) & 26.8 & & \\
\hline
\end{tabular}


Table 2. Cont'd.

\begin{tabular}{|c|c|c|c|c|c|}
\hline Characters & Unit & Categories & $\%$ & Mean & $\mathrm{SD}$ \\
\hline \multirow{3}{*}{$\begin{array}{l}\text { Subsistence } \\
\text { pressure }\end{array}$} & \multirow[t]{3}{*}{ Score } & Low ( up to $0.01 \mathrm{ha}$ ) & 1.3 & \multirow{3}{*}{0.22} & \multirow{3}{*}{0.21} \\
\hline & & Medium ( above 0.01 to $0.43 \mathrm{ha}$ ) & 83.5 & & \\
\hline & & High (above 0.43 ha) & 15.2 & & \\
\hline \multirow{3}{*}{$\begin{array}{l}\text { Farming } \\
\text { experience }\end{array}$} & \multirow{3}{*}{$\begin{array}{l}\text { Actual } \\
\text { (year) }\end{array}$} & Low (Up to 10$)$ & 48.9 & \multirow{3}{*}{11.40} & \multirow{3}{*}{5.21} \\
\hline & & Medium (11-20) & 42.9 & & \\
\hline & & High (above 20) & 8.2 & & \\
\hline \multirow{3}{*}{$\begin{array}{l}\text { Annual family } \\
\text { income }\end{array}$} & \multirow[t]{3}{*}{ Taka } & Low (Tk75248 to Tk 90000) & 2.6 & \multirow{3}{*}{$\begin{array}{c}\mathrm{Tk} \\
202822.5 \\
2\end{array}$} & \multirow{3}{*}{$\begin{array}{l}1127 \\
32.45\end{array}$} \\
\hline & & Medium (Tk 90001- Tk 315000) & 84.5 & & \\
\hline & & High (above Tk 315000) & 12.6 & & \\
\hline \multirow{5}{*}{$\begin{array}{l}\text { Organizational } \\
\text { participation }\end{array}$} & \multirow[t]{5}{*}{ Score } & No participation $(0)$ & 7.8 & \multirow{5}{*}{4.67} & \multirow{5}{*}{3.23} \\
\hline & & Low participation (1-4) & 48.5 & & \\
\hline & & Medium participation (5-7) & 21.6 & & \\
\hline & & High participation (8-16) & 22.1 & & \\
\hline & & Very high participation (above 16) & - & & \\
\hline \multirow{3}{*}{$\begin{array}{l}\text { Extension } \\
\text { contact }\end{array}$} & \multirow[t]{3}{*}{ Score } & Low (up to 13 ) & 18.2 & \multirow{3}{*}{19.33} & \multirow{3}{*}{6.28} \\
\hline & & Medium (14 to 25$)$ & 63.2 & & \\
\hline & & High (above 25) & 18.6 & & \\
\hline \multirow{4}{*}{$\begin{array}{l}\text { Participation } \\
\text { in training } \\
\text { programme }\end{array}$} & \multirow[t]{4}{*}{ Score } & No training $(0)$ & 43.7 & \multirow{4}{*}{1.28} & \multirow{4}{*}{1.35} \\
\hline & & Poor training (1-3) & 52.4 & & \\
\hline & & Medium training (4-5) & 2.2 & & \\
\hline & & High training (above 5) & 1.7 & & \\
\hline \multirow[t]{3}{*}{ Innovativeness } & \multirow{3}{*}{$\begin{array}{l}\text { No. of } \\
\text { years used }\end{array}$} & Low innovativeness (1-16) & 10.8 & \multirow{3}{*}{28.54} & \multirow{3}{*}{6.91} \\
\hline & & Medium innovativeness (17-32) & 55.4 & & \\
\hline & & High innovativeness (Above 32) & 33.8 & & \\
\hline \multirow{3}{*}{$\begin{array}{l}\text { Attitude } \\
\text { towards potato } \\
\text { production } \\
\text { technology }\end{array}$} & \multirow[t]{3}{*}{ Score } & Unfavorable (Up to 70) & 17.7 & \multirow{3}{*}{86.16} & \\
\hline & & Moderately favorable (71-101) & 71.4 & & 15.42 \\
\hline & & Highly Favorable (102 and Above) & 10.8 & & \\
\hline Knowledge on & Score & Low (Up to 8) & 23.8 & & \\
\hline potato & & Medium (9-14) & 60.6 & 11.39 & 3.07 \\
\hline technologies & & High (15 and above) & 15.6 & & \\
\hline
\end{tabular}

Data presented in Table 2 reveal that the highest proportion of the respondents was identified as middle aged (50.60\%), with secondary level of education $(34.20 \%)$, small family size $(47.20 \%)$, medium farm size $(56.30 \%)$, 
medium subsistence pressure $(83.50 \%)$, low farming experience $(48.90 \%)$, medium income $(84.80 \%)$, low organizational participation $(48.50 \%)$, medium extension contact $(63.20 \%)$, poor training experience $(52.40 \%)$, medium innovativeness $(55.40 \%)$, moderately favourable attitude $(71.40 \%)$, and medium knowledge $(60.6 \%)$ on improved potato production technologies.

\section{Extent of adoption of improved potato production technologies}

Technology parameters recommended by BARI ( Anonymous, 2006) like use of quality potato seed, varieties, optimum planting time, seed size, spacing, balanced fertilizer, fertilizer application method, irrigation, earthing up, and plant protection were considered. Adoption status of all the above technologies by the respondent farmers is described in Table 3.

In Munshiganj Sadar, highest proportion of the respondents belonged to high adoption category in the case of BARI recommended potato variety $(72.6 \%)$, optimum planting time (87.7\%), use of balanced fertilizer (45.2\%), whereas medium adoption categories were found in quality potato seed $(52.1 \%)$, proper seed size (47.9\%), fertilizer application methods (71.2\%), optimum irrigation (89\%), earthing up $(84.9 \%)$, plant protection $(74 \%)$ and low adoption categories were found in maintaining proper spacing $(42.5 \%)$.

In Pirganj of Rangpur, highest proportion of the respondents was observed in high adoption category in case of practicing BARI recommended potato variety (77\%), optimum planting time (83.8\%), whereas medium adoption categories were found in use of quality potato seed $(64.9 \%)$, balanced fertilizer $(43.2 \%)$, proper seed size (52.7\%), fertilizer application methods (87.8\%), optimum irrigation (97.3\%), earthing up (86.5\%), plant protection (93.2\%), and low adoption categories were found in maintaining proper spacing (64.9\%).

In Shibganj of Bogra, highest proportion of the respondents were found in high adoption category in case of practicing BARI recommended potato variety (75\%), optimum planting time $(86.9 \%)$, whereas medium adoption categories were found in use of quality potato seed $(52.4 \%)$, balanced fertilizer $(47.6 \%)$, fertilizer application methods (78.6\%), optimum irrigation (95.2\%), earthing up $(88.1 \%)$, plant protection $(76.2 \%)$, and low adoption categories were found in maintaining proper spacing $(59.5 \%)$ and proper seed size $(57.1 \%)$.

It was observed that BARI recommended potato varieties and optimum planting time were highly practiced by the respondents, while they no knowledge in maintaining proper spacing. 
Table 3. Distribution of the respondents according to their adoption of improved potato production technologies in different study areas.

\begin{tabular}{l|c|c|c|c|c|c|c|c|c}
\hline \multirow{2}{*}{ Technology parameters } & \multicolumn{7}{c}{ Extent of adoption (\% respondents) } \\
\cline { 2 - 10 } & \multicolumn{2}{c}{ Munshiganj Sadar } & \multicolumn{2}{c}{ Pirganj, Rangpur } & \multicolumn{3}{c}{ Shibganj, Bogra } \\
\cline { 2 - 10 } & LA & MA & HA & LA & MA & HA & LA & MA & HA \\
\hline Use of quality potato & 16.4 & 52.1 & 31.5 & 20.3 & 64.9 & 14.9 & 22.6 & 52.4 & 25.0 \\
seed & & & & & & & & & \\
BARI recommended & - & 27.4 & 72.6 & - & 23.0 & 77.0 & - & 25.0 & 75.0 \\
varieties & & & & & & & & & \\
Optimum planting time & 2.7 & 9.6 & 87.7 & - & 16.2 & 83.8 & - & 13.1 & 86.9 \\
Seed size & 43.8 & 47.9 & 8.2 & 47.3 & 52.7 & - & 57.1 & 38.1 & 4.8 \\
Spacing & 42.5 & 38.4 & 19.2 & 64.9 & 28.4 & 6.8 & 59.5 & 33.3 & 7.1 \\
Balanced fertilizer & 11.0 & 43.8 & 45.2 & 14.9 & 43.2 & 41.9 & 17.9 & 47.6 & 34.5 \\
Fertilizer application & - & 71.2 & 28.8 & - & 87.8 & 12.2 & - & 78.6 & 21.4 \\
method & & & & & & & & & \\
Irrigation & 4.1 & 89.0 & 6.8 & - & 97.3 & 2.7 & 1.2 & 95.2 & 3.6 \\
Earthing up & - & 84.9 & 15.1 & - & 86.5 & 13.5 & - & 88.1 & 11.9 \\
Plant protection & 1.4 & 74.0 & 24.7 & - & 93.2 & 6.8 & 3.6 & 76.2 & 20.2 \\
\hline
\end{tabular}

LA-Low Adoption (Up to 33), MA-Medium Adoption (34 to 66), HA-High Adoption (above 66).

A score for overall adoption of improved technologies in potato production was computed for each respondent to ascertain the extent of his/her combined adoption score of the ten improved technology parameters (Table 4). Among the 10 recommended potato production technologies, majority $(56.3 \%)$ of the respondents had medium adoption of quality seed, (74.9\%) high adoption of BARI recommended varieties, $(86.1 \%)$ high adoption of optimum planting time, (49.8\%) low adoption of optimum seed size, (55.8\%) low adoption of optimum spacing, (45\%) medium adoption of balanced fertilizer, (79.2\%) medium adoption of recommended fertilizer application methods, (93.9\%) medium adoption of optimum irrigation, (86.6\%) medium adoption of recommended earthing up, (74\%) medium adoption of recommended plant protection measures, respectively. Amin and Islam (2009) conducted a study on adoption of recommended potato production practices in Naogaon district of Bangladesh and found that a majority $(57 \%)$ of the farmers had low to medium adoption of recommended potato production practices. 
Table 4. Distribution of the potato farmers according to their overall extent of adoption in improved potato production technologies

\begin{tabular}{|c|c|c|c|c|c|}
\hline \multirow{2}{*}{$\begin{array}{l}\text { Improved technology } \\
\text { parameter }\end{array}$} & \multicolumn{3}{|c|}{ Extent of adoption (\% respondents) } & \multirow{2}{*}{$\begin{array}{c}\text { Mean } \\
\text { adoption } \\
\text { index }\end{array}$} & \multirow{2}{*}{$\begin{array}{l}\text { Rank } \\
\text { order }\end{array}$} \\
\hline & Low & Medium & High & & \\
\hline $\begin{array}{l}\text { BARI recommended } \\
\text { varieties }\end{array}$ & - & 25.1 & 74.9 & 86.52 & $1^{\mathrm{st}}$ \\
\hline Optimum planting time & 0.9 & 13 & 86.1 & 83.79 & $2^{\text {nd }}$ \\
\hline Irrigation & 1.7 & 93.9 & 4.3 & 66.76 & $3^{\text {rd }}$ \\
\hline Plant protection & - & 74 & 26 & 64.30 & $4^{\text {th }}$ \\
\hline $\begin{array}{l}\text { Fertilizer application } \\
\text { method }\end{array}$ & - & 79.2 & 20.8 & 60.53 & $5^{\text {th }}$ \\
\hline Balanced fertilizer & 14.7 & 45 & 40.3 & 58.57 & $6^{\text {th }}$ \\
\hline Earthing up & - & 86.6 & 13.4 & 54.44 & $7^{\text {th }}$ \\
\hline Use of quality potato seed & 19.9 & 56.3 & 23.8 & 50.16 & $8^{\text {th }}$ \\
\hline Spacing & 55.8 & 33.3 & 10.8 & 40.91 & $9^{\text {th }}$ \\
\hline Seed size & 49.8 & 45.9 & 4.3 & 36.23 & $10^{\text {th }}$ \\
\hline
\end{tabular}

Islam (2007) conducted a study on adoption of recommended potato cultivation practices in Gazaria thana of Munshigonj district and found that 72 percent of farmers had high adoption of recommended variety and 51 percent had high adoption of plant protection measures. Muttaleb et al. (1998) conducted a study on adoption level and its constraints of selected recommended potato technology. They found that the level of adoption of modern variety, quality seed, recommended spacing, recommended earthing up, and optimum planting time were almost medium. High and low adoption was found in recommended irrigation, seed size, respectively.

\section{Potato yield obtained by the respondent farmers}

Potato yield obtained by the respondent farmers ranged from 10.64 to $33.68 \mathrm{t} / \mathrm{ha}$, the average being $24.03 \mathrm{t} / \mathrm{ha}$ and the standard deviation being 5.40 . The average yield $(24.03 \mathrm{t} / \mathrm{ha})$ of potato in the three selected areas was much higher than the national average yield (17.80 t/ha) (DAE, 2010).

Data presented in Table 5 showed that in Munshiganj Sadar, the highest proportion $(53.40 \%)$ of the farmers belonged to high potato yield farmer category and 46.60 percent were medium potato yield farmer category. In Shibganj, maximum portion $(58.80 \%)$ of the farmers belonged to medium potato yield category followed by 36.5 percent low and 4.70 percent large potato yield category and in Pirgachha, the highest proportion (79.50\%) of the farmers were found in medium potato yield farmer category followed by 13.70 percent low and 
6.80 percent large potato yield farmer category. It was revealed that most of the farmers (53.40\%) in Munshiganj Sadar obtained higher yield that might be due to adoption of improved potato production technologies

Table 5. Distribution of the potato farmers according to potato yield obtained in different study areas.

\begin{tabular}{l|c|c|c|c|c|c|c}
\hline \multirow{2}{*}{ Category } & \multicolumn{2}{c|}{$\begin{array}{c}\text { Munshiganj } \\
\text { Sadar }\end{array}$} & \multicolumn{2}{c|}{ Shibganj } & \multicolumn{2}{c|}{ Pirgachha } & All \\
\cline { 2 - 9 } & No. & $\%$ & No. & $\%$ & No. & $\%$ & $\%$ \\
\hline $\begin{array}{l}\text { Low potato yield farmer } \\
(10-19 \text { t/ha) }\end{array}$ & 0 & 0 & 31 & 36.50 & 10 & 13.70 & 17.70 \\
$\begin{array}{l}\text { Medium potato yield farmer } \\
\text { (between 19-29 t/ha) }\end{array}$ & 34 & 46.60 & 50 & 58.80 & 58 & 79.50 & 61.50 \\
$\begin{array}{l}\text { High potato yield farmer } \\
\text { ( above 29 t/ha) }\end{array}$ & 39 & 53.40 & 4 & 4.70 & 5 & 6.80 & 20.80 \\
Total & 73 & 100 & 85 & 100 & 73 & 100 & 100 \\
\hline
\end{tabular}

Multiple regression analysis was done which indicated that multiple $\mathrm{R}$ and $\mathrm{R}^{2}$ values in full model regression were 0.918 and 0.842 respectively (Table 6). The corresponding F- value (117.11) was found highly significant. It indicates that all the selected technology parameter have a joint contribution to the harvested yield of potato i.e. $R=0.918$ and corresponding $R^{2}$ value is 0.842 , which means that all technologies have jointly contributed $84.2 \%$ of the total variation of potato yield. Among the 10 technology parameters except recommended seed size, all were found to have positive significant relationship with potato yield.

\section{Socio-economic characteristics of the potato farmers and adoption of improved potato production technologies}

Age, family size, organizational participation, training and innovativeness of the potato growers were not important indicator concerning the adoption of recommended production technologies (Table 7). Age was, however, found positive and significant, which was consistent with the findings of (Etoundi and Dia, 2008 and Nwakor et al., 2011). Positive relation of organizational participation with technology adoption was found by Amin and Islam, 2009. Level of education and adoption of recommended potato production technologies were significantly and positively correlated. That is, the educated farmers are more interested in adoption of recommended potato production technologies. This finding is in harmony with the report of Amin and Islam, 2009 and Hoque et al., 2010. Farm size of the respondent had significant relationship with their 
Table 6. Multiple regression analysis showing influence of technological factors on the yield of potato.

\begin{tabular}{c|l|c|c|c}
\hline Sl. No. & \multicolumn{1}{|c|}{ Independent variables } & $\begin{array}{c}\text { Regression } \\
\text { coefficients } \\
\text { (b values) }\end{array}$ & t values & $\begin{array}{c}\text { Level of } \\
\text { Significance } \\
\text { (p values) }\end{array}$ \\
\hline 1 & Use of quality seed & .070 & 5.566 & $.000^{* *}$ \\
2 & BARI recommended varieties & .071 & 8.950 & $.000^{* *}$ \\
3 & Optimum planting time & .057 & 5.429 & $.000^{* *}$ \\
4 & Seed size & .015 & .747 & .456 \\
5 & Spacing & .027 & 2.252 & $.025^{*}$ \\
6 & Balanced fertilizer & .110 & 9.307 & $.000^{* *}$ \\
7 & Fertilizer application method & .025 & 2.491 & $.013^{* *}$ \\
8 & Irrigation & -.087 & -3.838 & $.000^{* *}$ \\
9 & Earthing up & .044 & 2.508 & $.013^{* *}$ \\
10 & Plant protection & .143 & 6.132 & $.000^{* *}$ \\
\hline
\end{tabular}

$\mathrm{R}=0.918, \mathrm{~F}=117.11 * *, \mathrm{R}^{2}=0.842$

$*=$ significant at $5 \%$ level

$* *$ = significant at $1 \%$ level

adoption of recommended technologies which also supported by Hoque et al., 2010. Annual income of the respondent had also significant positive relationship with the adoption of recommended technologies i.e., the higher is the annual income of the respondents, the more they adopted recommended technologies. It implied that with increased income, respondents were able to procure inputs for potato production so that they invested more which brought for them higher income. Extension contact had significant positive relationship with their adoption of recommended potato production technologies. It is obvious that contact with extension agents might have changed the attitude of respondents and thus they become interested to adopt new technology. This finding is very consistent with several studies carried out by Amin and Islam, 2009 and Hoque et al., 2010. Farming experience also had positive relation with adoption of potato technology which is consistent with the study of Rahm and Huffman, 1984. Other variables like subsistence pressure, attitude and knowledge on potato production technologies were as well positively correlated with adoption of potato production technologies. 
Table 7. Relationships between socio-economic profile of the respondents and their adoption of improved potato production technologies.

\begin{tabular}{l|c|c}
\hline \multicolumn{1}{c}{ Independent variable } & Dependent variable & Co-efficient of correlation (r) \\
\hline Age of farmer & & 0.019 \\
Farmers education & & $0.260(* *)$ \\
Family size & & -0.023 \\
Farm size & & $0.281\left(^{* *}\right)$ \\
Subsistence pressure & Adoption of & $0.232(* *)$ \\
Farming experience & recommended potato & $0.180(* *)$ \\
Annual income & production technologies & $0.339\left(^{*}\right)$ \\
Organizational participation & -0.097 \\
Extension contact & & $0.302(* *)$ \\
Training & & 0.074 \\
Innovativeness & & 0.057 \\
Attitude & & $0.825(* *)$ \\
Knowledge & & $0.689(* *)$ \\
\hline
\end{tabular}

$*$ significant at $5 \%$ level

$* *$ significant at $1 \%$ level

\section{Conclusion}

- Among the 10 recommended potato production technologies, majority of the respondents had high adoption of BARI recommended varieties (74.9\%), optimum planting time $(86.1 \%)$, while medium adoption of quality potato seed $(56.3 \%)$, balanced fertilizer $(45 \%)$, recommended fertilizer application methods (79.2\%), optimum irrigation (93.9\%), earthing up (86.6\%), recommended plant protection measures (74\%), and low adoption of optimum seed size (49.8\%), optimum spacing (55.8\%), respectively.

- Findings revealed that farmers' adoption of improved potato production technologies contributed significantly to potato yield. Where highest (53.4\%) proportion of the respondents in Munshiganj Sadar belonged to high potato yield farmer category, while medium potato yield categories were found in other two areas i.e., Shibganj (58.80\%) and Pirgachha (79.50\%).

- Adoption of potato production technologies by the potato farmers was increased with higher level of education, larger farm size, higher subsistence pressure, and annual income, greater contact with sources of information and high level of knowledge. 
- Socio-economic characteristics of the potato growers have profound influence on their adoption of potato production technologies.

\section{Recommendation}

- Field level extension personnel (Both from GOs and NGOs) should provide training to the potato growers in maintaining proper seed size and optimum spacing.

- There is a need for strengthening extension services by GOs and NGOs to ensure a continuous technical know-how to the potato growers for enhancing their skills and knowledge to enhance potato yield.

- Government (especially DAE, BADC) and non- government (BRAC) development initiatives should consider the findings of the study in formulating any capacity strengthening programmes and projects related to potato production.

\section{References}

Ali, M. S. and A. Hoque. 2011. Potato for food Security in SAARC Countries; SAARC Seed Congress and Fair 2011, Dhaka, Bangladesh.

Amin, M. R. and M. R. Islam. 2009. Adoption of recommended potato production practices by the farmers in some selected areas of Naogaon District. Bangladesh Journal of Extension Education 21(1 \&2): 125-132

Anonymous. 2006. Krishi Projukti Hand Book. $1^{\text {st }}$ part published by BARI, Joydebpur, Gazipur.

Bangladesh Bureau of Statistics (BBS). 2006. Yearbook of Agricultural Statistics in Bangladesh, Bangladesh Bureau of Statistics, Ministry of Planning, Government of the people's Republic of Bangladesh, Dhaka.

Bangladesh Bureau of Statistics (BBS). 2009. Yearbook of Agricultural Statistics in Bangladesh, Bangladesh Bureau of Statistics, Ministry of Planning, Government of the people's Republic of Bangladesh, Dhaka.

DAE. 2010. Agricultural Extension Manual. Dhaka: Department of Agricultural Extension.

Elias, S.M., M. R. U. Miah, M. J. Hossain, G. S. Torofder and M. S. Islam. 1992. Effect of potassium on the growth and yield of potato. Bangladesh J. Agril. Res.17(7): 91-93.

Etoundi, S. M. N. and B. K. Dia. 2008. Determinants of the adoption of improved varieties of maize in Cameroon: Case of CMS 8704. Proceedings of the African Economic Conference 2008, 97-413.

Hoque, M. Z., M. E. Haque, M. S. I. Afrad and M. A. Hossain. 2010. Adoption of farming technology by the charland farmers. Bangladesh Journal of Extension Education 22 ( 1 \&2):49-55 
Islam, M. M. 2007. Adoption of recommended potato cultivation practices. M. S. (Ag. Extn. \& inf. System) Thesis, Department of Agricultural Extension and Information System, Sher e Bangla Agricultural University, Dhaka-1207.

Kashem, M. A. 2004. Measurement of Adoption. In: Fundamentals of Extension Education. BAU, Mymensingh. P.64-67.

Kothari, C. R. 2004. Research Methodology. Methods \& Techniques (First Edition), 4835/24 Ansari Road, Daryaganj, New Delhi 110002.

Muttaleb, M. A., M. A. Hossain and M. A. Rashid. 1998. Adoption level and constraints of selected recommended potato technology. Bangladesh J. of Training and Development 11(1 \& 2): 13-17.

Nwakor, F. N., G. E. Ifenkwe, B. C. Okoye, F. N. Nummadu, H. N. Anyaegbunam, T. O. Ekedo and C. E. Onyia. 2011. Socio-Economic Factors Affecting Adoption of Improved Cassava Varieties among Farmers in Abia State. Journal of Agriculture and Social Research (JASR) 11(1): 63-71.

Rahm, M. R. and W.E. Huffman. 1984. The adoption of reduced tillage: The role of man, capital and other variables. American J. of Agril. Econ. 66(4): 405-413. 